\title{
ANALISIS INTANGIBLE FACTORS YANG MEMPENGARUHI PENENTUAN HARGA PRODUK KARYA SENI
}

\author{
Kusriniarti Dwi Lestariningsih dan Subagyo \\ Jurusan Teknik Mesin dan Industri Program Studi Teknik Industri \\ Fakultas Teknik Universitas Gadjah Mada \\ Email: k.dwilestari@gmail.com
}

\begin{abstract}
This research aims to develop a new quantitative method to determine painting pricing based on 10 intangible factors, i.e. curator, amount of exhibition, painter's year of birth, painting's years of made, auction record, estimation price, exhibition place, painting media, painting size, and previous sales record. The selling price data are obtained from six auction houses. Kano Model and Linear Regression Model are used to examine the relation between pricing and each variable. Based on the model development scheme, there are 6 alternative models that can be obtained. Each model then was evaluated by cross-validation procedure using 21 data. Based on the value of $R^{2}$ for each model, the Kano Model with variable previous sales is the best model with $R^{2}$ of $70 \%$.
\end{abstract}

Keywords: price, intangible factors, Kano Model, Linear Regression

\begin{abstract}
ABSTRAK
Penelitian ini mengembangkan metode kuantitatif untuk menentukan penentuan harga lukisan berdasarkan 10 intangible factors, antara lain panel rekomendator, jumlah pameran, tahun lahir seniman, tahun pembuatan karya, auction record, estimasi harga, tempat penjualan, media yang digunakan, ukuran, dan penjualan sebelumnya. Data penjualan diperoleh dari enam tempat lelang. Penelitian ini menggunakan Model Kano dan Regresi Linear Berganda untuk menganalisis hubungan antara penentuan harga dengan masing-masing variabel. Berdasarkan kerangka model yang berhasil dibangun, terdapat enam model alternatif. Masing-masing model dievaluasi dengan cross validation menggunakan 21 data. Berdasarkan nilai $\mathrm{R}^{2}$ masing-masing model, model terbaik diperoleh dari Model Kano dengan mengikutsertakan variabel penjualan sebelumnya. Model ini memiliki $\mathrm{R}^{2} 70 \%$.
\end{abstract}

Kata Kunci: harga, intangible factors, model kano, regresi linear 


\section{KUSRINIARTI DWI LESTARININGSIH, SUBAGYO * ANALISIS INTANGIBLE FACTORS YANG \\ MEMPENGARUHI PENENTUAN HARGA PRODUK KARYA SENI}

\section{PENGANTAR}

Harga merupakan bagian bisnis yang dapat ditentukan dengan beragam strategi. Strategi penentuan harga yang biasa dilakukan, antara lain mark-up pricing, target return pricing, competition based pricing, dan value pricing (Irawan, 2003). Mark up pricing, dan target return pricing umumnya mengacu pada keuntungan yang diinginkan atas biaya yang telah dikeluarkan. Competition pricing fokus pada kompetitor, tetapi masih mengacu pada biaya yang dikeluarkan. Sedangkan value pricing tidak sekedar memperhitungkan biaya, tetapi lebih fokus pada apa yang akan diperoleh konsumen ketika membeli produk.

Value pricing menetapkan harga dengan fokus pada pelanggan. Penentuan harga tidak dimulai dengan menghitung biaya produksi, namun berusaha memberikan jawaban atas pertanyaan pada harga berapa konsumen mau membayar produk atau jasa yang ditawarkan (Irawan, 2003). Biaya tidak lagi diperhitungkan sebagai komponen utama harga karena value pricing dapat didekati dengan analisis nilai intangible. Istilah intangible dipahami sebagai nonmonetary profit yang memberikan nilai di luar produk (Canibano et al, 2000). Aset intangible merupakan representasi dari reputasi, brand, dan atribut lain yang memungkinkan untuk memperoleh pendapatan yang lebih besar.

Produk karya seni seperti lukisan merupakan salah satu contoh produk yang memiliki nilai intangible. Secara fisik, karya seni hanya sedikit membawa nilai jual. Biaya raw material seperti kanvas, kertas, dan cat umumnya kecil (Marshall dan Forrest, 2001). Akan tetapi, produk ini dijual dengan harga tinggi karena konsumen membayar untuk sebuah status, estetika, dan harapan atas nilai jual kembali (Velthuis, 2003). Secara simbolis, karya seni memiliki nilai tambah lain yang melebihi produk secara fisik.

Beberapa faktor yang mempengaruhi harga produk lukisan, antara lain nama pelukis, subyek lukisan, ukuran, dan style (Kompas, 2011) Faktor-faktor tersebut tidak dapat diperhitungkan atau diukur dalam proses memproduksi karya seni secara fisik, tetapi memberikan dampak pada besar kecilnya harga yang ditawarkan oleh pelukis.

Tidakseperti produk pada umumnya, nilai harga dari suatu karya seni lebih kepada nilainilai budaya dan sosial yang dirasakan oleh konsumen (Schonfeld, dkk: 2007). Meskipun demikian, intangible factors penentuan harga produk karya seni tetap memiliki aspek ekonomi yang dapat diukur. Pendekatan penentuan harga dengan mempertimbangkan faktor intangible pada produk karya seni dilakukan oleh Marshall dan Forrest (2011) yang menganalisis faktor-faktor intangible produk karya seni dengan menggambarkan sebuah market valuation framework.

Dalam framework tersebut digambarkan aspek sosiologis, estetika, dan teori pemasaran. Penentu harga dalam framework ini terdiri dari beberapa faktor, antara lain seniman, produk, peran industri karya seni, dan peran pembeli. Akan tetapi, penelitian tersebut masih sebatas penggambaran aspek intangible secara kualitatif.

Penentuan harga karya seni yang melibatkan metode matematis dilakukan oleh Reddy dan Dass (2006) yang melakukan analisis terhadap dinamika dari pelelangan online pada seni modern India menggunakan functional data analysis. Dari penelitian tersebut diperoleh hasil bahwa status seniman dan harga memberikan pengaruh yang besar dalam lelang. Pada tahun 2007 bahwa analisis harga karya seni dalam kaitannya dengan pengaruh galeri dan reputasi seniman menggunakan metode undercut proof equilibrium (UPE) dengan teknik regresi linier (Schonfield, dkk: 2007). Di sisi lain, Hodgson (2011) juga meneliti harga produk karya seni dengan obyek lukisan-lukisan di Perancis. Penelitian ini menggunakan regresi hedonik dalam menganalis data. Penelitian ini mengungkapkan beberapa tolok ukur harga lukisan, antara lain faktor pelukis, tempat lukisan dijual, media yang digunakan, genre, dan ukuran. 
Beberapa penelitian telah dilakukan menggunakan metode kuantitatif berbasis regresilinier.Padabeberapakasuslain, analisis pengaruh faktor tidak hanya menganalisis hubungan secara linier, juga non-linier. Salah satunya adalah analisis kesuksesan produk yang pendekatannya dilakukan dengan Metode Kano (Pramadani, 2011). Model Kano adalah model yang dikembangkan untuk menganalisis keinginan pelanggan yang membaginya dalam tiga kategori, yaitu logaritmik, linier, dan eksponensial.

Metode analisis pengaruh faktor yang melibatkan hubungan non-linier juga telah banyak digunakan dalam aplikasi model kuantitatif. Hanya saja, metode ini belum diaplikasikan untuk menguji hubungan pengaruh faktor intangible yang mempengaruhi penentuan harga produk karya seni. Untuk itu, analisis faktor penentuan harga produk karya seni masih dapat dikembangkan dengan memanfaatkan metode yang mampu menganalisis hubungan non-linier seperti Model Kano.

Produk seni lukis yang dijual pada beberapa balai lelang baik yang nasional maupun internasional. Terdapat 85 data penjualan secara lelang yang diperoleh dari beberapa pelukis Indonesia di beberapa balai lelang.Balai lelang yang diacu sebagai sumber data antara lain Sotheby's, Christie's, Cempaka, Larasati, Masterpiece, dan Sidharta. Sotheby's dan Christie's merupakan balai lelang internasional yang memiliki ruang pameran di berbagai kota di dunia.

Pada artikel ini dijabarkan beberapa tahap alir penelitian seperti gambar nomor 1 . Secara umum, penelitian dimulai dari pengumpulan data harga jual dan data variabel-variabel yang menjadi faktor intangible. Setelah data diuji berdasarkan asumsi statistik yang diperlukan, data diolah berdasarkan prosedur metode Model Kano dan Regresi Linier Berganda untuk kemudian dibangun beberapa model matematis. Pembangunan model dilakukan dengan dua perlakuan data, yaitu data tanpa standardisasi skala untuk masing- masing variabel dan data dengan skala standar untuk semua variabel. Setelah model dibangun, dilakukan pengujian beberapa model menggunakan parameter $R^{2}$ dan validasi silang. Berdasarkan pengujian model, dipilih satu model yang dapat memberikan kemampuan prediksi harga terbaik.

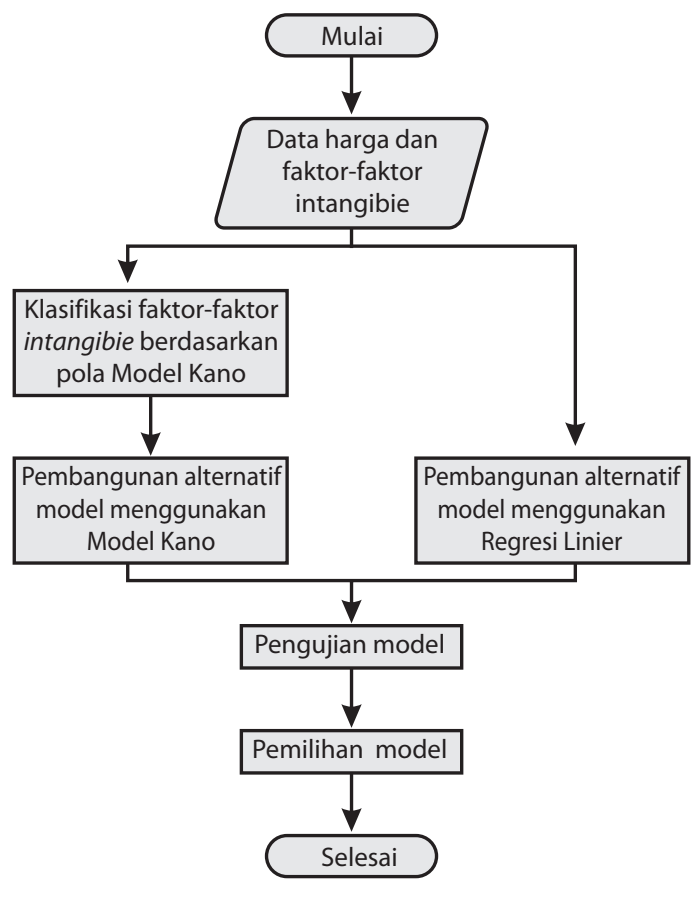

Gambar 1. Diagram Alir Penelitian

\section{PEMBAHASAN}

Model dibangun berdasarkan kerangka pembangunan model pada Gambar nomor 2 .

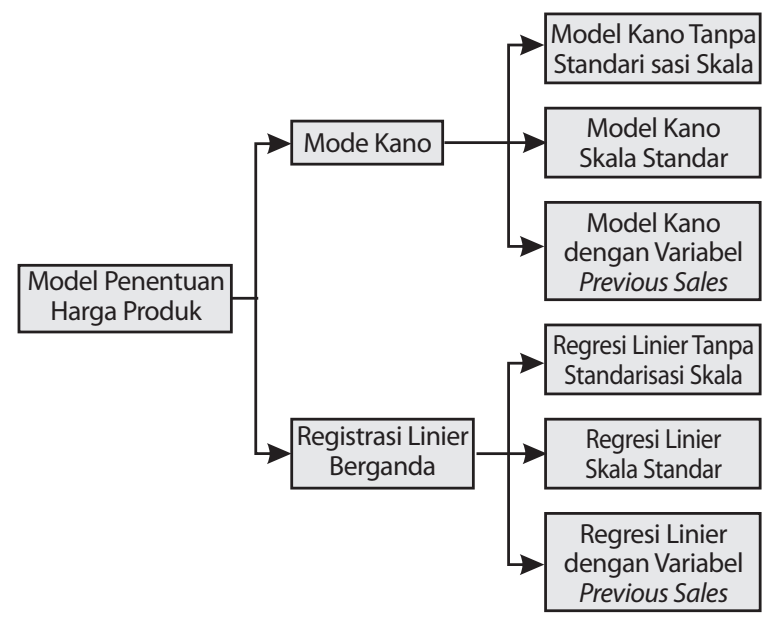

Gambar 2. Kerangka Pembangunan Model 


\section{KUSRINIARTI DWI LESTARININGSIH, SUBAGYO ANALISIS INTANGIBLE FACTORS YANG MEMPENGARUHI PENENTUAN HARGA PRODUK KARYA SENI}

Berdasarkan kerangka pembangunan model tersebut terdapat 6 (enam) model yang berhasil dibangun dari Model Kano dan Regresi Linier. Masing-masing metode memiliki 3 (tiga) jenis perlakuan data, yaitu model dengan data asli (tanpa standardisasi skala), model dengan skala standar, dan model dengan tambahan variabel previous sales. Variasi pengolahan data dilakukan untuk mendapatkan perbandingan model, sehingga dapat diperoleh model yang terbaik.

Model dibangun dari $3 / 4$ data yang diperoleh, dan sisanya digunakan untuk validasi. Masing-masing model memberikan koefisien determinasi yang berbeda-beda seperti yang ditunjukkan pada Tabel 3.1.

Tabel 1.

Hasil R² Masing-Masing Model

\begin{tabular}{|l|l|}
\hline \multicolumn{1}{|c|}{ Model } & \multicolumn{1}{|c|}{$\mathrm{R}^{2}$} \\
\hline $\begin{array}{l}\text { Model Kanotanpa } \\
\text { standardisasi skala }\end{array}$ & 0.43 \\
\hline Model Kano skala standar & 0.23 \\
\hline $\begin{array}{l}\text { Model Kanodengan variabel } \\
\text { previous sales }\end{array}$ & 0.86 \\
\hline $\begin{array}{l}\text { Regresi Linier Berganda tanpa } \\
\text { standardisasi skala }\end{array}$ & 0.35 \\
\hline $\begin{array}{l}\text { Regresi Linier Berganda skala } \\
\text { standar }\end{array}$ & 0.50 \\
\hline $\begin{array}{l}\text { Regresi Linier Berganda } \\
\text { dengan variabel previous sales }\end{array}$ & 0.85 \\
\hline
\end{tabular}

Kemampuan prediksi masing-masing model diuji dengan validasi silang holdout menggunakan 1/4 data (Hair, dkk: 2010). Hasil validasi memberikan nilai $\mathrm{R}^{2}$ yang ditampilkan pada Tabel 3.2.

Tabel 2.

$\mathrm{R}^{2}$ Validasi

\begin{tabular}{|l|l|}
\hline \multicolumn{1}{|c|}{ Model } & \multicolumn{1}{|c|}{$\mathrm{R}^{2}$} \\
\hline $\begin{array}{l}\text { Model Kano tanpa standardisasi } \\
\text { skala }\end{array}$ & 0.03 \\
\hline Model Kano skala standar & 0.31 \\
\hline
\end{tabular}

\begin{tabular}{|l|l|}
\hline $\begin{array}{l}\text { Model Kano dengan variabel } \\
\text { previous sales }\end{array}$ & 0.70 \\
\hline $\begin{array}{l}\text { Regresi Linier Berganda } \\
\text { tanpa standardisasi skala }\end{array}$ & 0.05 \\
\hline $\begin{array}{l}\text { Regresi Linier Berganda skala } \\
\text { standar }\end{array}$ & -0.05 \\
\hline $\begin{array}{l}\text { Regresi Linier Berganda dengan } \\
\text { variabel previous sales }\end{array}$ & 0.54 \\
\hline
\end{tabular}

Berdasarkan pengujian koefisien determinasi dan evaluasi prediksi dengan validasi silang, model yang dapat merepresentasikan data secara keseluruhan adalah Model Kano dengan variabel previous sales. Model ini menghasilkan nilai $\mathrm{R}^{2} 0.86$ dan memberikan hasil prediktif tertinggi di antara modelmodel lain, yaitu 0.70.

Model Kano tersebut terdiri dari 3 (tiga) persamaan untuk masing-masing kategori. Persamaan untuk kategori must be ditunjukkan pada persamaan, yaitu tabel nomor 1. Kategori tersebut terdiri dari variabel banyaknya pameran, tahun lahir, auction record, tahun pembuatan, ekspektasi harga minimal, dan ukuran. Persamaan kategori one-dimensional terdiri dari variabel balai, media, dan previous sales ditunjukkan pada persamaan tabel nomor 2. Kemudian persamaan kategori eksponensial yang terdiri dari variabel curator ditunjukkan oleh persamaan nomor 3 (tiga) di bawah ini.

$$
\begin{aligned}
\mathrm{Y}_{1}= & 183567+61961,87\left[\ln (\mathrm{X}]_{2}\right)+9725,87 \ln \left(\mathrm{x}_{3}\right) \\
& +5553,78\left[\ln \left(\mathrm{X}_{3}\right)+100708,3\left[\ln (\mathrm{X}]_{6}\right)\right. \\
& +417985,1 \ln \left(\mathrm{X}_{7}\right)-39757,3 \ln \left(\mathrm{X}_{11}\right) \\
\mathrm{Y}_{2}= & -91108+39894.98 \mathrm{X}_{9}+23896.91 \mathrm{X}_{10} \\
& +505546.7 \mathrm{X}_{12} \\
\mathrm{Y}_{3}= & 22855,85 \text { e1, }^{51 \mathrm{x}_{1}}
\end{aligned}
$$

Secara keseluruhan, Model Kano yang meliputi kategori must be, one-dimensional, dan eksponensial tersebut ditunjukkan oleh persamaan di bawah ini.

$Y_{2}=-64360+6101,52 \ln \left(Y_{1}\right)+0,91 Y_{2}$

$$
+0,0036 \mathbf{e}^{0,00016 \gamma_{3}}
$$




\section{SIMPULAN}

Dari hasil dan pembahasan yang telah dilakukan dapat disimpulkan sebagai berikut: pertama, Faktor-faktor intangible yang mempengaruhi penentuan harga produk terdiri dari 3 (tiga) faktor, yaitu faktor seniman, faktor produk, dan faktor perantara. Faktor seniman dapat dilihat dari kurator, banyaknya pameran, auction record, usia seniman, tahun pembuatan karya, estimasi harga seniman, dan previous sales. Faktor produk dapat dilihat dari ukuran karya dan media yang digunakan. Sedangkan perantara ditinjau dari tempat penjualan.

Kedua, Telah berhasil dibangun model matematis yang dapat digunakan untuk memprediksi harga produk karya seni berdasarkan faktor-faktor intangible. Model terbaik diperoleh dari Model Kano yang terdiri dari 10 variabel dengan kemampuan prediktif sebesar $70 \%$. Kemampuan prediktif ini lebih besar daripada model yang dibangun dengan Regresi Linier. Berdasarkan model tersebut, faktor intangible yang termasuk dalam kategori must be adalah banyaknya pameran, tahun lahir, tahun pembuatan, auction record, estimasi harga minimal, dan ukuran. Variabel yang dikategorikan dalam kategori one-dimensional adalah balai lelang dan media. Sedangkan attractive terdiri dari variabel rekomendator.

Untuk itu, Perlu adanya penyesuaian (justification) yang lebih detil dalam menghitung masing-masing variabel, seperti memberikan pembobotan. Data harga menggunakan data penjualan di galeri, untuk mengetahui apakah terdapat perbedaan ketika suatu karya seni diperjualbelikan di balai lelang atau di galeri umum. Kemudian dengan melibatkan faktor konsumen yang membeli produk karya seni, karena konsumen juga mempengaruhi penentuan harga produk ketika terjadi penawaran pada proses lelang.

\section{DAFTAR PUSTAKA}

Canibano, L, Garcia-Ayuso, M, dan Sanchez, M., 2000, "Accounting for Intangibles: A Literature Review", Journal of Accounting Literature, 19, 102-130.

Hair, J, Black W.C., Babin, B.J., dan Anderson, R.E., 2010, “Mulivariate Data Analysis", New York Prentice-Hall.

Hodgson, D., 2011, “An Analysis of Pricing and Return in The Market for French Canadian Painting", Applied Economic, 43, 63-73.

Irawan, Handi, 2003, "Winning Strategy", Gramedia Pustaka Utama, Jakarta.

Kompas, 2011, Lukisan Bisa Jadi Investasi Bernilai Milyaran, [diakses pada 12 November 2011 pukul 20.00 WIB] URL: http://nasional.kompas. com/read/2010/06/30/10260894/ function.simplexml-load-file.

Marshall, K. P dan Forrest, P. J., 2011. "A Framework for Identifying Factors That Influence Fine Art Valuations From Artist to Consumers", The Marketing Management Journal, Vol 21, No.1, 111-123.

O'Neil, K. M, 2011, “Context Of Exchange And The Pricing Of Visual Art", University of Arizona.

Pramadani, A. I., 2011, Modifikasi Model Matematis Kesuksesan Produk Berbasis Model Kano, Tugas Akhir, Program Studi Teknik Industri, Universitas Gadjah Mada, Yogyakarta.

Reddy, S. K dan Dass, M., 2006, "Modeling On-Line Art Auction Dynamics Using Functional Data Analysis", Statistical Science, Vol 2, No.2, 179-193.

Witten, L dan Frank, E., 2000, “Data Mining: Practical Machine Learning Tools and Techniques With Java Implementation", University of Waikoto, New Zeland. 
KUSRINIARTI DWI LESTARININGSIH, SUBAGYO ANALISIS INTANGIBLE FACTORS YANG MEMPENGARUHI PENENTUAN HARGA PRODUK KARYA SENI

Schonfeld, S dan Reistaller, A., 2007, Velthuis, Olav, 2003, "Symbolic Meaning Of "The Effect of Gallery and Artist Reputation on Prices in the Primary Market for Art: a Note", Science and Business Media. Vol 31, 143-153. Prices: Constructing the Value of Contemporary Art in Amsterdam and New York Galleries", Theory and Society, Vol 32, No.2, 181-215. 